\title{
Bożena SŁOMIŃSKA*
}

\section{Planowanie przestrzenne w rozwoju społeczno-gospodarczym gmin}

Celem artykułu jest omówienie znaczenia planowania przestrzennego w rozwoju społeczno-gospodarczym polskich gmin, w tym w rozwoju lokalnego rynku. Kwestie gospodarowania przestrzenią oraz jego prawnego uregulowania budzą wiele emocji wśród urbanistów i przedstawicieli organizacji samorządowych zarówno w kraju, jak i za granicą, z uwagi na jego rolę w harmonizacji rozwoju społeczno-gospodarczego regionów. Dyskutowana jest konieczność zmian zarówno charakteru planów, jak i procedur planowania. W Polsce postuluje się szersze włączenie polityk branżowych w sferę planowania przestrzennego, co spowoduje objęcie wszelkich działań w ich zakresie prawem miejscowym. Rezultatem powinno być pełne wyeliminowanie uznaniowych decyzji urzędników ze sfery lokalizacji lokalnych inwestycji.

W artykule prezentowane są wyniki badania, przeprowadzonego w 2002 roku przez Instytut Rynku Wewnętrznego i Konsumpcji w 450 krajowych gminach, mającego za zadanie rozpoznanie zachowań gmin w obszarze planowania przestrzennego i regulowania rozwoju handlu na lokalnych rynkach oraz zebranie ich opinii o funkcjonowaniu ustawy o zagospodarowaniu przestrzennym w aspekcie lokalizacji wielkopowierzchniowych obiektów handlowych. Badanie objęło powiaty grodzkie, gminy miejskie oraz miejsko-wiejskie, których łączna liczba wynosi 871 . Ponieważ uzyskano wypowiedzi z przeszło $50 \%$ jednostek należących do objętej badaniami populacji, a rozkład wojewódzki respondentów odzwierciedla istniejącą strukturę, wyniki badania można uznać za reprezentatywne dla całej zbiorowości trzech wymienionych grup gmin ${ }^{1}$.

\section{Wprowadzenie}

Planowanie przestrzenne prowadzone jest na trzech poziomach, tj. kraju, województw i gmin. Każdy z tych poziomów ma odmienną skalę w zakresie czasu i przestrzeni, inny poziom generalizacji problemów i odmienny status prawno-organizacyjny. Tworzą one wobec siebie układ zhierarchizowany, ale bez podporządkowania.

Planowanie przestrzenne w skali krajowej ma za zadanie stymulować i inspirować rozwój oraz tworzyć ramy dla wyrównywania niepożądanych dysproporcji występujących w zagospodarowaniu przestrzennym poszczególnych

Autorka jest pracownikiem Instytutu Rynku Wewnętrznego i Konsumpcji w Warszawie. Artykuł wpłynął do redakcji w lutym $2003 \mathrm{r}$.

1 Pełne wyniki badania [U. Kłosiewicz-Górecka, B. Słomińska, 2002]. 
regionów. Jego horyzont czasowy jest relatywnie długi, a poziom generalizacji problemów bardzo duży. Ma on charakter studialny i przyjmuje formę koncepcji, która stanowi podstawę decyzyjną dla działań rządu.

Planowanie regionalne na poziomie województw ma za zadanie konsolidować regionalne struktury przestrzenne i określać kierunki zagospodarowania przestrzennego dostosowane do strategicznych kierunków rozwoju społecznego i gospodarczego przy zachowaniu ciąglości kulturowej i tożsamości regionalnej zamieszkującej je społeczności. Operuje średnim horyzontem czasu. Przyjmuje formę planu zagospodarowania przestrzennego województwa, który nie jest jednak aktem prawnym powszechnie obowiązującym, nie może więc stanowić podstawy wydawania jakichkolwiek decyzji administracyjnych. Plan ten odzwierciedla w przestrzeni przyjętą strategię rozwoju regionalnego oraz nosi cechy planów struktury w odniesieniu do zadań ponadlokalnych.

Planowanie na poziomie gmin ma stworzyć podstawy merytoryczne i formalnoprawne do realizacji przedsięwzięć przewidywanych na wszystkich poziomach planowania przestrzennego. Operuje krótkim horyzontem czasowym wynikającym z założonego okresu realizacji zamierzeń. Spełnia funkcję regulacyjną i realizacyjną w stosunku do przyjętych programów i zadań, co wymaga wysokiej szczegółowości ustaleń.

W warunkach polskich gmina jest podstawą systemu organizacyjnego planowania przestrzennego. Ustalanie przeznaczenia i zasad zagospodarowania terenu zaliczone jest do jej zadań własnych. Jej organy uchwalają wiążące plany zagospodarowania przestrzennego (tzw. plany miejscowe), a ich ustalenia kształtują sposób wykonania prawa własności nieruchomości.

Jednakże plan miejscowy nie jest obligatoryjny. Gmina może - ale nie musi - uchwalić plan miejscowy. Może go sporządzić tylko dla części obszaru. Tam, gdzie nie ma planu, decyzje dotyczące przeznaczenia i zasad zagospodarowania terenu podejmowane są wprost na podstawie ustaw. Ustawa ściśle określa sytuacje, kiedy plan miejscowy sporządza się obowiązkowo.

Obligatoryjny jest natomiast drugi dokument planistyczny opracowywany przez gminy, tj. studium uwarunkowań i kierunków zagospodarowania przestrzennego, który obejmuje cały obszar gminy. Jest to tzw. akt kierownictwa wewnętrznego gminy, który wiąże organy gminy i jednostki organizacyjne im podporządkowane, natomiast nie obowiązuje innych jednostek publicznych. Studium gminne wyznacza obszary, które zostaną objęte planami miejscowymi.

Ustawa o zagospodarowaniu przestrzennym ${ }^{2}$ zaledwie w sposób ogólny określa problematykę, jaka powinna być przedmiotem studium gminnego i planów miejscowych. Elastyczność ustaleń dokumentów planistycznych pozwala modyfikować problematykę studium w zależności od potrzeb. Władze gminy posiadają w tym zakresie dużą swobodę w podejmowaniu decyzji.

2 Ustawa z dnia 7 lipca 1994 r. o zagospodarowaniu przestrzennym (Dz.U. 1994 r., nr 89, poz. 1690) z późn. zm. 


\section{Plan zagospodarowania przestrzennego jako zasadnicze narzędzie rozwoju gmin w Polsce}

Organy samorządu gminnego w Polsce dysponują na tyle szerokimi kompetencjami w sferze gospodarki przestrzennej, że przy ich uźyciu mogą nie tylko sprawować kontrolę użytkowania terenu, ale również wpływać aktywnie na lokalną gospodarkę. Zestaw instrumentów ekonomicznych pozostających w ich gestii ma znacznie mniejszą siłę oddziaływania, w rezultacie czego realizacja szeregu celów związanych z pobudzaniem lokalnego rozwoju gospodarczego następuje głównie poprzez dostępne instrumenty w sferze gospodarki przestrzennej, a uzupełniająco za pośrednictwem instrumentów finansowo-ekonomicznych.

Do zasadniczych instrumentów pozwalających na prowadzenie racjonalnej gospodarki przestrzenią należą przede wszystkim:

- studium uwarunkowań i kierunków zagospodarowania przestrzennego gminy;

- miejscowe plany zagospodarowania przestrzennego;

- decyzje o warunkach zabudowy i zagospodarowania terenu;

- inne decyzje organizacyjne wydawane na podstawie przepisów prawa ustawowego;

- uchwalone stawki podatków i opłat lokalnych;

- ustalone zasady obrotu nieruchomościami gminnymi (zasobami gruntów i budownictwa komunalnego).

Rolę i znaczenie poszczególnych grup narzędzi w sterowaniu rozwojem gospodarczym gminy można spróbować ocenić poprzez zakres tematyczny uchwał podejmowanych przez rady gmin. Według informacji uzyskanych w badanych gminach przedmiotem uchwał rad w minionej kadencji były najczęściej (dane w \% odpowiedzi):

- plan zagospodarowania przestrzennego - 70,4,

- wysokość opłat lokalnych - 70,1,

- procedury sprzedaży i najmu lokali - 44,3,

- procedury sprzedaży i dzierźawy gruntów - 28,4,

- decyzje dotyczące warunków zabudowy terenu - 22,0.

Zaprezentowane zestawienie wyników potwierdza, że podstawowymi instrumentami regulacji gospodarki lokalnej przez gminy jest plan zagospodarowania przestrzennego oraz narzędzia regulacji finansowej, tj. podatki i opłaty nakładane na funkcjonujące podmioty gospodarcze.

Nie bez znaczenia dla takiej hierarchii tematycznej uchwał rad gmin jest również fakt, iż z końcem 2002 roku upłynął dwukrotnie już przedłużany termin ważności miejscowych planów zagospodarowania przestrzennego uchwalonych przed 1 stycznia 1995 roku. Było to zapewne przyczyną zintensyfikowania prac wielu gmin nad studiami uwarunkowań i kierunków zagospodarowania przestrzennego oraz nowymi planami miejscowymi. W przypadku uchwalenia studium i przystąpienia do sporządzania planu miejscowego bądź jego zmiany jeszcze w roku 2002 stare plany zachowają moc obowiązującą przez kolejny rok, tj. do 31 grudnia 2003 roku. 
Pozyskane w badanej populacji gmin informacje wskazują na następujący stan zaawansowania prac gmin nad koncepcją przestrzennego zagospodarowania ich terenów (w \% wypowiedzi):

- gmina uchwaliła studium gminne i plan miejscowy dla obszarów przewidzianych w studium - 1,8,

- gmina uchwaliła studium gminne i przystąpiła do sporządzania bądź zmiany planów miejscowych - 70,1,

- gmina uchwaliła studium gminne, ale dotychczas nie podjęła prac nad planami miejscowymi - 15,5,

- prace nad studium gminnym są w wysokim stopniu zaawansowane i przewiduje się jego uchwalenie w 2002 roku - 8,1,

- gmina nie widzi możliwości uchwalenia studium gminnego do końca 2002 roku - 4,5.

Pewne różnice w postępie prac nad koncepcją przestrzennego zagospodarowania rysują się pomiędzy gminami o charakterze miejskim, miejsko-wiejskim i powiatami grodzkimi (rys. 1). Te ostatnie w przeszło $90 \%$ uchwaliły studium gminne i przystąpiły do sporządzania miejscowych planów zagospodarowania przestrzennego.

Rys. 1. Ocena stopnia zaawansowania prac gminy nad koncepcją jej przestrzennego zagospodarowania

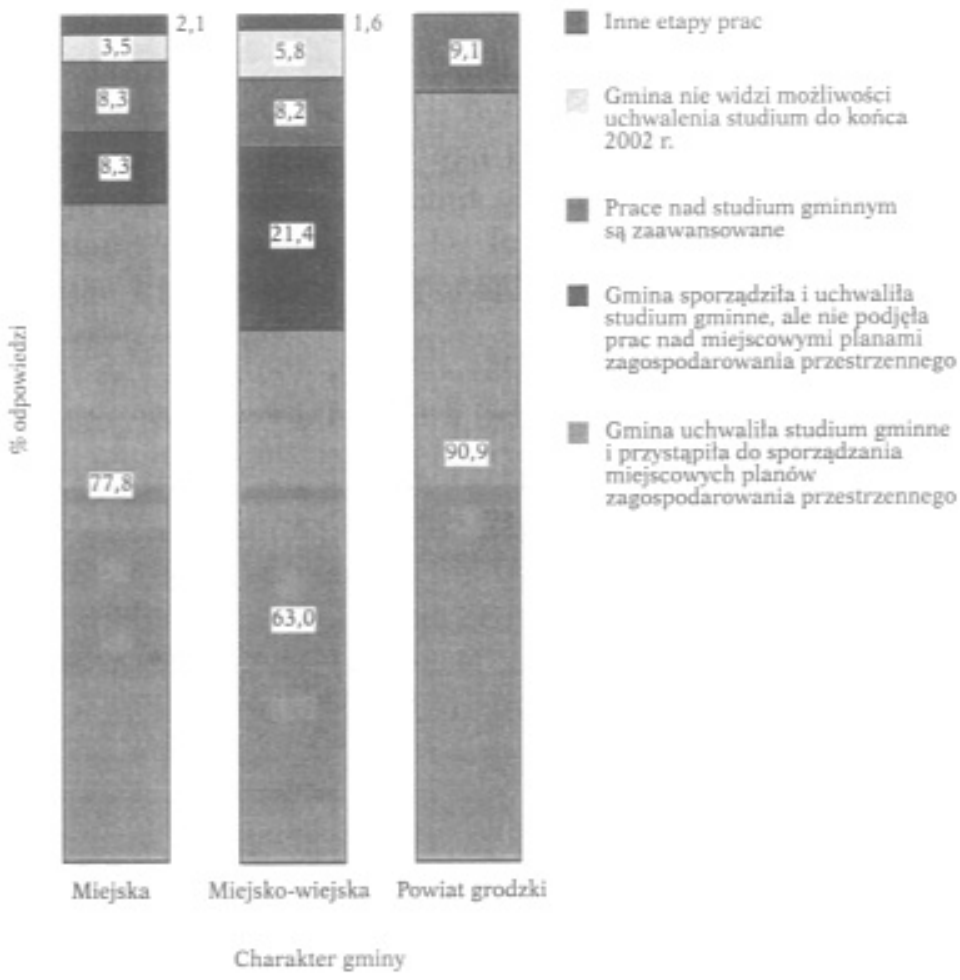

Źródło: Badanie IRWiK z 2002 r. 
Według ocen specjalistów od zagadnień gospodarki przestrzennej właściwie skonstruowany plan miejscowy może ułatwić lokalny rozwój i sprzyjać rozwiązaniu gminnych problemów. Za pomocą planu samorząd gminny może bowiem głęboko ingerować w kształt zagospodarowania przestrzennego poszczególnych części administrowanego przez siebie obszaru, reprezentując przy tym interes zbiorowości lokalnej, nawet kosztem interesu prywatnego.

O ile studium uwarunkowań i kierunków zagospodarowania przestrzennego gminy określa zamiary władz gminnych w dziedzinie gospodarki przestrzennej na bliższą i dalszą przyszłość, o tyle plan miejscowy powinien szczegółowo określić przeznaczenie wszystkich terenów, których dotyczy. W jego uzupełnieniu, w oparciu o prace studialne nad uwarunkowaniami i kierunkami zagospodarowania gminy, w dalszych etapach mogą być konstruowane plany szczegółowe, np. rozwoju handlu oraz przedsięwzięć inwestycyjnych gminy.

Zasadniczym problemem związanym ze sporządzaniem planu miejscowego jest stosunkowo wysoki koszt (łącznie ze studium gminnym może to wynieść nawet kilkanaście procent budżetu gminy), czego skutkiem jest częste sporządzanie planów nie dla całości obszaru gminy, lecz wybranych jej części. Wśród zbadanych w 2002 roku gmin udział terenu gminy objętego planami miejscowymi kształtował się w sposób zróżnicowany:

\begin{tabular}{c|c} 
powierzchnia gminy objeta planami & \% badanych gmin \\
\hline do $5 \%$ & 37,9 \\
$5,1-10 \%$ & 19,3 \\
$10,1-20 \%$ & 18,1 \\
$20,1-50 \%$ & 9,9 \\
ponad 50\% & 14,8
\end{tabular}

Z uzyskanych informacji wynika, że przeszło $57 \%$ gmin objęło planami miejscowymi co najwyżej $10 \%$ powierzchni gminy, chociaż $w$ badanej populacji wystąpiły równieź gminy, które objęły planami miejscowymi całą swoją powierzchnię.

Ponadto częstym mankamentem miejscowego planu zagospodarowania był i w wielu planach jeszcze jest jego zbyt ogólny charakter. Np. w planie określa się tereny przeznaczone pod zabudowę z funkcjami usługowymi, w tym również handlowymi, natomiast szczegóły polegające na dokładnym sprecyzowaniu funkcji przypisanych do planowanych obiektów ujmowane są w decyzji administracyjnej o warunkach zabudowy i zagospodarowania terenu. Prowadziło to niekiedy do błędnych decyzji lokalizacyjnych np. dużych sklepów, umożliwiało naruszanie prawa i związaną z tym korupcję [Dutkowska, 2002].

Pomimo wspomnianych ułomności plan miejscowy stanowi weryfikator przedsięwzięć inwestycyjnych podejmowanych na terenie gminy. Na jego podstawie wydawane są decyzje administracyjne co do możliwości zabudowy i sposobu zagospodarowania każdej działki objętej planem. Brak planu może więc sparaliżować bądź co najmniej utrudnić tę działalność. Wszelkie decyzje o warunkach zabudowy i zagospodarowania terenu wymagają bowiem wówczas specjalnego trybu postępowania administracyjnego. 


\section{Plan zagospodarowania przestrzennego jako narzędzie regulacji rozwoju handlu}

Miejscowy plan zagospodarowania przestrzennego stanowi tym samym jedno z narzędzi regulacji rozwoju lokalnego handlu. W opinii władz zbadanych gmin zakres regulacji lokalnego handlu kształtuje się następująco (w \% respondentów):

1) władze monitorują funkcjonowanie handlu na terenie gminy

i opracowują koncepcję jego rozwoju w dłuższym okresie

2) władze regulują wyłącznie rozwój handlowych obiektów

wielkopowierzchniowych przez wydawanie decyzji

o warunkach zabudowy i zagospodarowania terenu

3) regulacja rozwoju handlu w gminie następuje za

pośrednictwem opracowywania planów miejscowych,

w których określa się funkcje poszczególnych terenów,

w tym przeznaczonych pod ewentualną zabudowę handlową

67,3

4) na etapie planu miejscowego określa się nie tylko

przeznaczenie konkretnych terenów pod zabudowę handlową,

ale także wyznacza wielkość powierzchni sprzedażowej

przyszłych obiektów handlowych

5) regulacja rozwoju handlu następuje za pośrednictwem

zróżnicowania wysokości czynszów w lokalach użytkowych

przeznaczonych na cele handlu i usług

6) regulacja następuje przez wyznaczanie miejsc pod bazary

i targowiska

48,8

7) inne formy regulacji (sprzedaż lokali użytkowych najemcom, ustalanie wysokości opłat targowych i czynszowych)

8) władze gminy nie regulują rozwoju handlu

10,0

W uzyskanych wypowiedziach wyraźnie rysuje się wiodąca rola planów miejscowych, a także decyzji administracyjnych dotyczących wyznaczania miejsc pod bazary i targowiska w procesie regulacji rozwoju handlu. Trzeba jednak zaznaczyć, iż o ile przeszło $67 \%$ respondentów podkreśla znaczenie planów miejscowych jako weryfikatora przyszłych lokalizacji dla obiektów pełniących funkcje handlowe, to zaledwie niecałe $12 \%$ zwraca uwagę na jego rolę w określaniu wielkości powierzchni sprzedażowej przewidzianych w planie obiektów. W tym zakresie większe znaczenie mają z natury rzeczy bardziej szczegółowe decyzje o warunkach zabudowy i zagospodarowania terenu wydawane dla konkretnych obiektów handlowych. Dotychczas nie zawsze decyzje te były poprzedzone wnikliwym procesem programowo-planistycznym rozwoju różnego typu obiektów handlowych na terenie gminy. Obecnie (tzn. po znowelizowaniu ustawy o zagospodarowaniu przestrzennym) programowanie lokalizacji i powierzchni obiektów powinno przyjąć formę stałego trybu postępowania w sferze gminnej polityki przestrzennej. 
W znowelizowanej ustawie o zagospodarowaniu przestrzennym ${ }^{3}$ przewidziano bowiem specjalne procedury stosowane przy lokalizacji wielkopowierzchniowych obiektów handlowych. Zgodnie z zapisem ustawy plan miejscowy oraz narzędzie jego realizacji w postaci decyzji o warunkach zabudowy i zagospodarowania terenu zaczęły (pod określonymi warunkami) pełnić rolę regulatora powstawania tego rodzaju obiektów na terenie gminy. Partycypantem procesu decyzyjnego w tym zakresie stała się tym samym cała społeczność lokalna, która posiada prawo do wglądu w projekty planów miejscowych przed ich zatwierdzeniem oraz do złożenia ewentualnych protestów i zarzutów dotyczących zaproponowanych w planie ustaleń przestrzennych.

Przeznaczenie w planie miejscowym terenów pod budowę wielkopowierzchniowych obiektów handlowych (w rozumieniu ustawy obiektów o powierzchni sprzedażowej powyżej $1000 \mathrm{~m}^{2}$ - w gminach o liczbie mieszkańców do 20000 oraz o powierzchni sprzedażowej powyżej $2000 \mathrm{~m}^{2}$ - w gminach o liczbie mieszkańców ponad 20 000) zostało obwarowane wymogiem sporządzenia i dołączenia do wglądu mieszkańców prognozy skutków budowy tych obiektów dla rynku pracy, komunikacji, istniejącej sieci handlowej oraz zaspokojenia potrzeb i interesów konsumentów. Prognoza jest również niezbędna, jeżeli w miejscowym planie nie przeznaczono terenów pod budowę wielkopowierzchniowych obiektów handlowych, ale występują w nim tereny pod usługi i handel, na których można rozważyć budowę dużych obiektów (np. wprowadzając zmianę do planu miejscowego) oraz o ile został złożony wniosek o wydanie decyzji o warunkach zabudowy i zagospodarowania terenu pod budowę takiego obiektu, albo dla zmiany sposobu użytkowania obiektu budowlanego z przeznaczeniem na taki obiekt. Wyniki wykonanej prognozy stają się wówczas przedmiotem analizy, którą przeprowadza zarząd gminy i podstawą wniosku zarządu do rady gminy o podjęcie stosownej decyzji polegającej na wydaniu zgody bądź wprowadzeniu zakazu budowy takiego obiektu na danym terenie.

$\mathrm{Z}$ zapisów ustawy wynika zatem jednoznacznie znacząca rola, jaką w procesie decydowania o dopuszczeniu do budowy wielkopowierzchniowego obiektu handlowego odgrywać powinna prognoza skutków jego budowy dla całego środowiska lokalnego zarówno gospodarczego, jak i konsumenckiego, nie zawsze charakteryzującego się wspólnotą interesów. Staje się ona jednym z ważniejszych elementów uwzględnianych przy podejmowaniu przez władze gminy decyzji dotyczącej lokalizacji takiego obiektu na danym terenie.

Skutki znowelizowanej ustawy dla procesu regulowania rozwoju handlowych obiektów wielkopowierzchniowych postrzegane są przez przedstawicieli badanych gmin w sposób zróżnicowany. Rozrzut ocen wyrażają opinie skrajne:

- ustawa pozostaje bez wpływu na kierunki rozwoju handlu, zwiększa tylko wydatki budżetu gmin na wykonywanie prognoz;

- ustawa całkowicie zahamowała rozwój obiektów wielkopowierzchniowych.

3 Ustawa z dnia 13 lipca 2000 r. o zmianie ustawy o zagospodarowaniu przestrzennym (Dz.U. 01 nr 14, poz. 124). 
Jednakże większość wyrażanych opinii daje się zakwalifikować do kilku zasadniczych grup przekonań. Prezentuje je tablica 1.

Tablica 1

Ocena przydatnosci znowelizowanej ustawy o zagospodarowaniu przestrzennym dla regulowania procesu powstawania obiektow wielkopowierzchniowych

\begin{tabular}{|l|c|}
\hline \multicolumn{1}{|c|}{ Oceny } & \% wypowiedzi \\
\hline $\begin{array}{l}\text { 1. Ustawa ograniczy dynamikę powstawania wielkopowierzchniowych obiektów } \\
\text { handlowych }\end{array}$ & 25,8 \\
\hline $\begin{array}{l}\text { 2. Ustawa przyczyni się do lepszego wyboru szczególowej lokalizacji } \\
\text { wielkopowierzchniowych obiektów handlowych }\end{array}$ & 37,6 \\
\hline $\begin{array}{l}\text { 3. Ustawa nie zmieni już występującego dużego nasycenia rynku } \\
\text { wielkopowierzchniowymi obiektami handlowymi }\end{array}$ & 27,2 \\
\hline $\begin{array}{l}\text { 4. Rezultatem ustawy może być rozwój handlowych obiektów o powierzchni } \\
\text { sprzedażowej niewiele mniejszej niż określa ustawa }\end{array}$ & 41,0 \\
\hline 5. Inne oceny & 3,5 \\
\hline
\end{tabular}

Źródło: Badanie IRWiK z 2002 r.

Największa grupa respondentów przewiduje scenariusz rozwojowy, w którym nastąpi ograniczenie powierzchni sprzedażowej nowo budowanych obiektów handlowych do granic zapisanych w ustawie, co nie będzie wymagało uruchamiania procedury prognozowania skutków budowy tych obiektów. Tym samym zmniejszy się liczba nowo powstających obiektów wielkopowierzchniowych, dla których alternatywą mogą być sieci sklepów o średnich powierzchniach.

Jednocześnie respondenci zwracają uwagę na pozytywny wpływ, jaki ustawa może odegrać w procesie wyboru szczegółowej lokalizacji wielkopowierzchniowych obiektów handlowych. Konieczność większego uszczegółowienia planów pod kątem sprecyzowania terenów przeznaczonych pod budowę tych obiektów oraz szerokie konsultacje społeczne na etapie konstruowania planów powinny zaowocować korzystnymi dostosowaniami w tym zakresie. Już wcześniej stowarzyszenia kupieckie i stowarzyszenia mieszkańców podejmowały próby blokowania niepożądanych z ich punktu widzenia dużych inwestycji handlowych oraz próby wpływania na decyzje władz samorządowych w kwestii lokalizacji tych placówek, ale dopiero znowelizowana ustawa stworzyła szersze możliwości dla ingerencji społeczności lokalnej w decyzje tego dotyczące.

Kosztem takiego rozwiązania może być pewne wydłużenie procesu decyzyjnego ze względu na uczestnictwo wielu stron w postępowaniu administracyjnym (zrzeszenia handlowe, izby gospodarcze, partie, ekolodzy, zainteresowani mieszkańcy), a także pewne zniechęcenie ze strony inwestorów z uwagi na możliwość dużej ilości protestów składanych w związku z ich zamierzeniami inwestycyjnymi.

Interesująco ukształtował się rozrzut opinii w tym temacie pomiędzy gminami o różnym charakterze. Wśród zbadanych powiatów grodzkich w porównaniu z pozostałymi gminami wystąpił największy odsetek respondentów przekonanych, że ustawa ograniczy dynamikę powstawania wielkopowierzchniowych obiektów handlowych oraz przyczyni się do lepszego wyboru ich lokalizacji (rys. 2). 
Rys. 2. Ocena przydatnosci znowelizowanej ustawy dla regulowania procesu powstawania handlowych obiektow wielkopowierzchniowych

Ograniczy dynamikę powstawania wielkopowierzchniowych obiektów handlowych

Przyczyni sie do lepszego wyboru ich lokalizacj1

Nie zmieni juź występującego nasycenia obiektami wielkopowierzchniowymi

Doprowadzi do rozwoju handlowych obiektów o niewiele mniejszej powierzchni niż określa ustawa

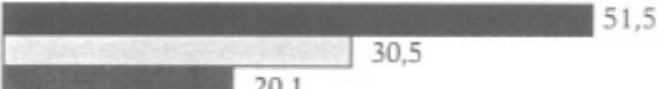

20,1
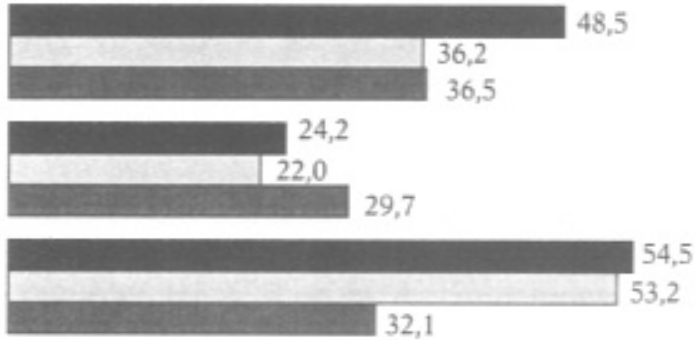

Inne

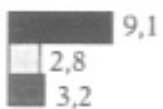

Powiat grodzki $\square$ Gmina miejska

Gmina micjsko-wiejska

Żródło: Badanie IRWiK z 2002 r.

W gminach miejskich oraz powiatach grodzkich dominowały opinie, że skutkiem ustawy będzie rozwój obiektów o powierzchni sprzedażowej nieco mniejszej niż objęta ustawowym wymogiem opracowania prognozy. Gminy miejsko-wiejskie natomiast $\mathrm{w}$ najmniejszym stopniu wiązały wymagania ustawowe z ograniczaniem dynamiki powstawania wielkopowierzchniowych obiektów handlowych, co może wynikać z faktu, iż rozwój wielkopowierzchniowych obiektów handlowych na terenach tych gmin jest relatywnie mniejszy niż w gminach pozostałych i zawsze był pod "szczególnym nadzorem" lokalnych grup kupieckich i gospodarczych.

Część respondentów jest jednak zdania, że politykę samorządu wobec wielkopowierzchniowych obiektów handlowych powinna odzwierciedlać "strategia rozwoju gminy" bądź też "studium gminne", w ramach których należałoby przeprowadzać rzetelne analizy zasadności lokalizacji takich obiektów na terenie gminy. Zdaniem krytyków omawianego rozwiązania legislacyjnego ustawa o zagospodarowaniu przestrzennym powinna służyć zapewnieniu ładu przestrzennego, a nie regulować tryb lokalizowania obiektów wielkopowierzchniowych.

\section{Gospodarowanie przestrzenią w pobudzaniu rozwoju lokalnej przedsiębiorczości}

Na podstawie ustaleń planu miejscowego tworzone są plany i programy działań gminy w poszczególnych sferach działalności publicznej, takie jak: plany rozwoju społeczno-gospodarczego gminy, plany inwestycyjne, programy gospodarowania zasobem gruntów publicznych, programy rozwoju infrastruk- 
tury, programy ochrony środowiska itp. oraz w dostosowaniu do nich różnorakie narzędzia regulacyjne, w tym reglamentacyjne, ekonomiczne, organizacyjne czy też dotyczące sfery zarządzania mieniem komunalnym. Ich zadaniem jest stworzenie podstaw do realizacji założeń gminnej polityki rozwoju społeczno-gospodarczego, którą wyrażają rozliczne cele ogólne, takie jak:

- rozwój lokalnego rynku pracy poprzez wspieranie lokalnej przedsiębiorczości oraz pozyskiwanie inwestorów zewnętrznych;

- rozwój usług z zakresu turystyki, kultury, handlu, gastronomii itp.;

- poprawa ładu przestrzennego gminy oraz porządkowanie jej struktury przestrzennej;

oraz cele cząstkowe w postaci:

- przygotowania terenów pod różne rodzaje działalności;

- tworzenia nowych obszarów działalności przy wykorzystaniu rezerw terenowych, wyposażenia ich w infrastrukturę techniczną i komunikacyjną;

- prowadzenia aktywnej polityki promocyjnej i informacyjnej dotyczącej gminy, jej walorów naturalnych i gospodarczych.

Wśród ogółu działań podejmowanych przez gminy dla celów pobudzania rozwoju lokalnej przedsiębiorczości daje się wyróżnić pięć zasadniczych grup, w zakresie których aktywność poszczególnych gmin - jak wynika z przeprowadzonych badań - jest dość zróżnicowana. Samoocena tej aktywności dokonana została przez respondentów w skali 1-5, gdzie 1 oznacza niepodejmowanie danego działania przez władze gminy, a nr 5 dużą aktywność władz gminy w tym zakresie - rys. 3 .

Rys. 3. Ocena $w$ skali 1 do 5 dzialań podejmowanych przez gminy dla rozwoju lokalnej przedsiębiorczosci

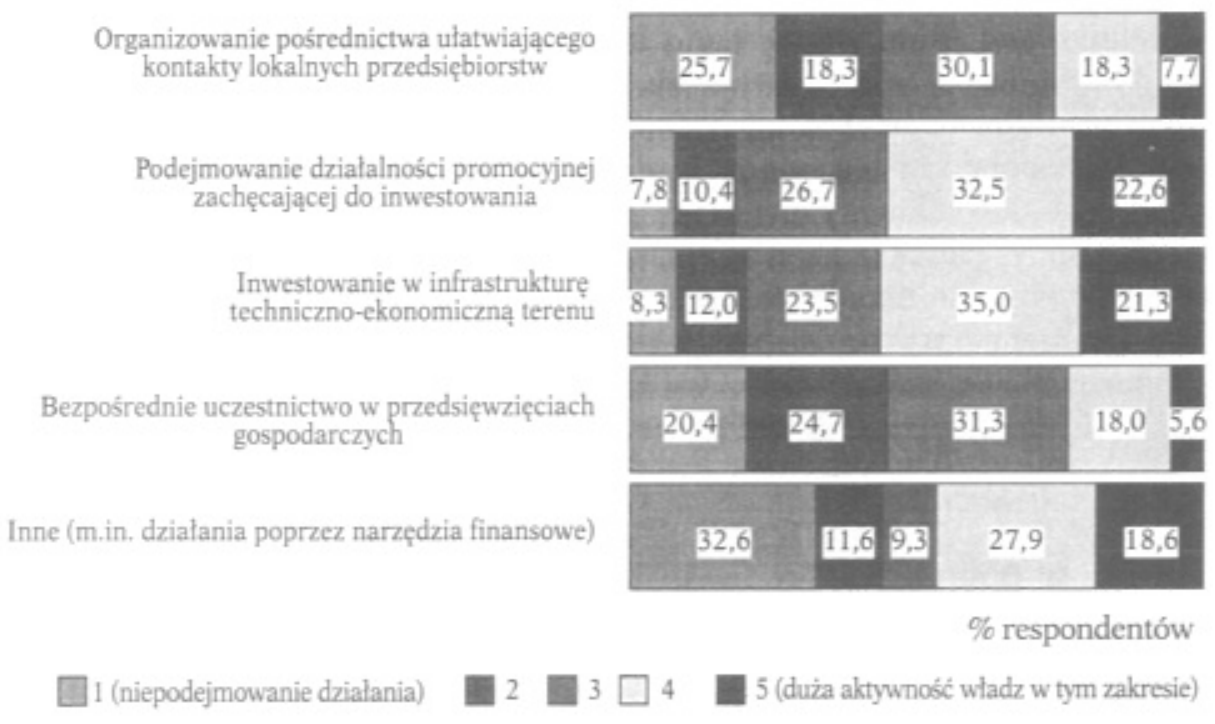

Źródlo: Badanie IRWiK z 2002 r. 
Szczególnie dużą aktywność władz gmin daje się zauważyć w sferze działalności promocyjnej oraz inwestowania w infrastrukturę techniczno-ekonomiczną terenu. Mniejszą, gdy w grę wchodzi organizowanie kontaktów lokalnych przedsiębiorców oraz posługiwanie się bodźcami ekonomiczno-finansowymi. Uwagę zwraca stosunkowo duża grupa gmin, które w bardzo małym zakresie, bądź wcale, uczestniczą bezpośrednio w przedsięwzięciach gospodarczych podejmowanych na terenie gminy.

Pogłębienie informacji o działaniach gmin, które w okresie ostatnich dwóch lat skierowane były na pobudzanie rozwoju lokalnej przedsiębiorczości, pozwoliło określić formy tych działań. Do najczęściej stosowanych należały: dbałość o rozwój dróg oraz rozwój telekomunikacji (tablica 2). Niewiele mniejszą rolę odgrywało wydzielanie działek pod różne rodzaje działalności, czyli przygotowywanie terenów pod inwestycje. Działanie to sprzężone dodatkowo z uzbrojeniem terenu jest uznawane nie tylko za jedno $\mathrm{z}$ narzędzi stymulowania przedsiębiorczości, ale także zwiększania konkurencyjności firm [Krajewski, 2000].

Tablica 2

Intensywnosé podejmowanych przez gminy działań służących rozwojowi przedsiębiorczosci badanych gmin

\begin{tabular}{|l|c|}
\hline \multicolumn{1}{|c|}{ Działania sprzyjające rozwojowi przedsiębionczosci } & $\%$ \\
\hline Wydzielanie działek pod zabudowę & 45,1 \\
\hline Dbaałość o rozwój dróg & 67,2 \\
\hline Dbałość o rozwój telekomunikacji & 51,6 \\
\hline Dbałość o podnoszenie kwalifikacji kadr & 21,9 \\
\hline Wprowadzanie ułatwień w procedurze urzẹdowej & 40,2 \\
\hline Inicjowanie ośrodków wspierania przedsiębiorczości & 33,0 \\
\hline Inne & 8,1 \\
\hline
\end{tabular}

Źródlo: Badanie IRWiK z 2002 r.

Wymienione działania wymagają na ogół mniejszych bądź większych wydatków inwestycyjnych ze strony gmin. Trzeba jednak podkreślić, iż np. w odniesieniu do dziedziny inwestycji handlowych coraz częściej stosowaną przez gminy praktyką jest przerzucanie odpowiedzialności za rozwój infrastruktury technicznej towarzyszącej budowie obiektów handlowych bezpośrednio na inwestorów. Nie dotyczy to oczywiście targowisk, których tworzenie i utrzymywanie w odpowiednim standardzie należy do zadań własnych gmin. Gminy próbują wiązać decyzje lokalizacyjne i wydawanie pozwoleń na budowę, szczególnie obiektów wielkopowierzchniowych, z gwarancjami, że inwestorzy poprawią stan dróg w okolicy czy też sfinansują nowe rozwiązania komunikacyjne.

Do zasadniczych narzędzi realizacji polityki samorządu gminnego w sferze rozwoju lokalnej przedsiębiorczości należą także instrumenty umożliwiające gospodarkę mieniem komunalnym, tj. procedury sprzedaży i najmu lokali oraz procedury sprzedaży i dzierżawy gruntów przeznaczonych pod inwestycje oraz polityka cenowa w tym zakresie. 
$\mathrm{Z}$ przeprowadzonych badań wynika, że prawie $65 \%$ gmin ma wypracowane zasady postępowania w zakresie gospodarowania lokalami, natomiast prawie $70 \%$ w zakresie gospodarowania gruntami i można ocenić to jako postęp w stosunku do stanu sprzed kilku lat, szczególnie jeżeli chodzi o sferę gospodarki gruntami. Procedury dotyczące najmu i sprzedaży lokali opracowane zostały wcześniej i już od kilku lat gminy realizują przyjętą w tym zakresie politykę. Zasady gospodarki gruntami komunalnymi wypracowywane były jednocześnie z aktualizacją planów zagospodarowania przestrzennego, dlatego powstawały nieco później.

Preferencje gmin w sferze gospodarowania mieniem obejmujące kilka najbliższych lat wskazują, że najwięcej gmin popiera sprzedaż zarówno własnych lokali, jak i gruntów komunalnych (rys. 4).

Rys. 4. Preferencje gmin w zakresie gospodarowania lokalami/gruntami na najbliższe 2-3 lata w badaniach z 2000 i 2002 roku

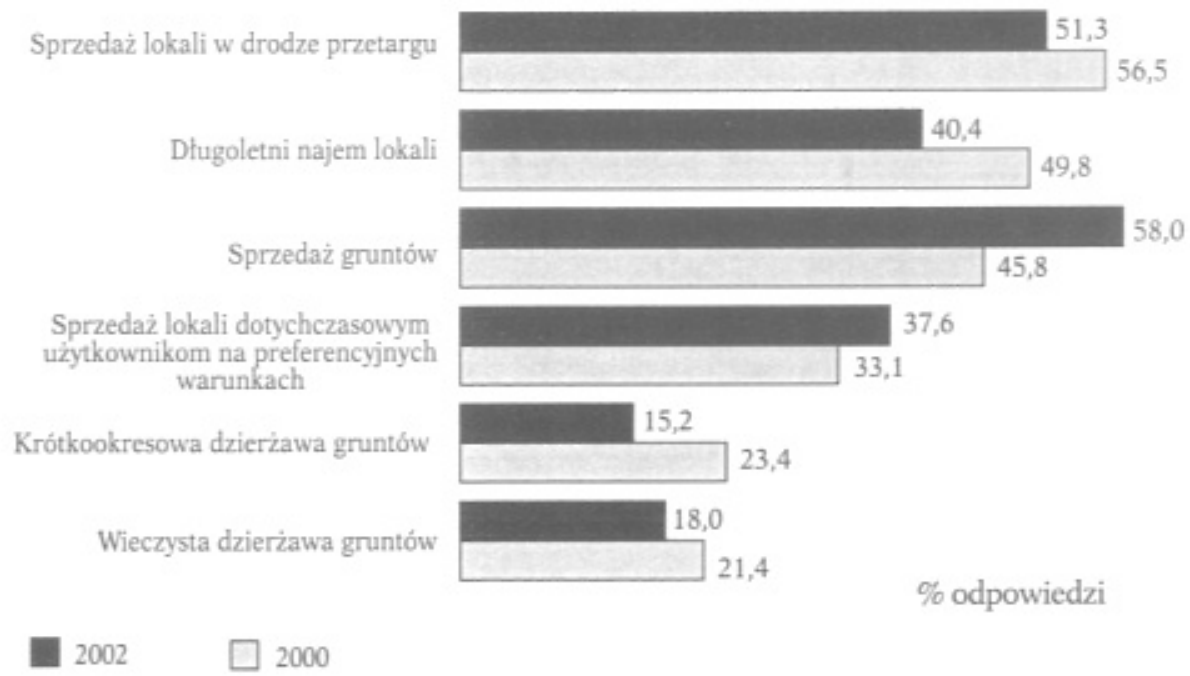

Zródło: Badania IRWiK z 2000 i 2002 r.

Nieruchomości oferowane przez gminy podlegają na ogół procedurze przetargowej, chociaż w myśl obowiązujących przepisów istnieje wiele możliwości odstąpienia od tej formy sprzedaży. Tym niemniej zaledwie $1 / 3$ badanych gmin przewiduje np. tryb sprzedaży lokali dotychczasowym użytkownikom na preferencyjnych warunkach, chociaż taka forma nie tylko stwarza poczucie większej stabilności w działaniu, ale również uwiarygodnia dbałość gmin w rozwój lokalnego rynku. W Kwidzynie np. samorząd gminy już w połowie lat 90 . sprzedał preferencyjnie lokale użytkowe dotychczasowym użytkownikom.

Zdarza się, że przeszkodą w sprzedaży lokali jest ich wysoka cena wynikająca $\mathrm{z}$ unormowań prawnych regulujących tryb i procedury wyceny mająt- 
ku. Dotyczy to w szczególności centrów dużych miast, o ukształtowanej substancji budowlanej.

Regulacja wysokości świadczeń z tytułu wynajmu mienia komunalnego uznawana jest za istotny instrument wspierania lokalnej przedsiębiorczości. Obniżki świadczeń w określonych przypadkach, choć oznaczają mniejsze wpływy do lokalnego budżetu, mogą stymulować pożądane przez gminy zachowania przedsiębiorców. Istotną sprawą jest skonstruowanie na tyle czytelnych i stabilnych mechanizmów najmu, aby ich zmiany nie zaskakiwały użytkowników w trakcie trwania umowy. W niektórych gminach wysokość czynszów co roku jest negocjowana z wynajmującymi lokale kupcami czy rzemieślnikami. Obszarem negocjacji są minimalne stawki czynszu najmu ustalane przez zarząd gminy oraz maksymalne ustalane przez państwo.

W kwestiach dzierżawy gruntów zdania gmin są podzielone. Generalnie mniej niż połowa badanych gmin jako rozwiązanie przyszłościowe przewiduje oddanie gruntów komunalnych w dzierżawę, co przy wysokiej stawce czynszu dzierźawnego w perspektywie długoterminowej może okazać się opłacalne. Reszta opowiada się za sprzedażą, co ich zdaniem korzystnie wplywa na rozwój miejscowego rynku budowlanego. Wariant dzierżawy wieczystej jako instrument gospodarowania gruntami preferowany jest przez gminy najrzadziej. Jednak niektóre $\mathrm{z}$ nich stosują to rozwiązanie, upatrując w nim różnorakie korzyści.

Władze lokalne coraz częściej wzmagają swoją aktywność w sferze zarządzania gruntami, zdając sobie sprawę z roli polityki przestrzennej w kreowaniu rozwoju gminy. Zaostrzająca się konkurencja między gminami wynikająca z nadpodaży nieruchomości municypalnych ${ }^{4}$, powoduje wzrost zainteresowania samorządów stosowaniem technik marketingowych, które mają wspomagać zarządzanie majątkiem komunalnym. Wpływ władz lokalnych na kształtowanie atrakcyjności nieruchomości gminnych rozpoczyna się już na etapie przygotowywania planu miejscowego. Odpowiednie usytuowanie nieruchomości w planowanym układzie przestrzennym miasta może wpłynąć korzystnie na stopień zainteresowania nimi przez przyszłych inwestorów.

\section{Uwagi końcowe}

Prezentowane wyniki badań zdają się potwierdzać tezę o dużym znaczeniu gospodarki przestrzennej w zarządzaniu procesami rozwoju gminy. Chociaż gminy stosują różnorakie narzędzia realizacji stojących przed nimi zadań, wiodąca rola polityki przestrzennej uwidacznia się przy każdej okazji. Tym większą wagę należałoby przywiązywać do procesów planowania przestrzennego prowadzonych na poziomie podstawowym, tj. do sporządzania studium gminnego i planu miejscowego, a także do wykorzystywania przyjętych dokumentów planistycznych w praktyce.

4 Tezę taką można znaleźć w artykule [M. Jendra, 2000]. 
Tymczasem opinie ekspertów oraz przedstawicieli samorządów lokalnych wskazują niejednokrotnie na zbyt luźny związek, a nawet rozbieżności pomiędzy tymi dwoma etapami gospodarowania przestrzenią. $\mathrm{O}$ ile w procesie sporządzania dokumentów planistycznych górę biorą chęci ochrony interesów publicznych, zapewnienia ładu przestrzennego i równoważenia rozwoju, o tyle w fazie ich realizacji częstym kryterium formułowania decyzji administracyjnych jest uwzględnianie interesów indywidualnych [Ziobrowski, 1998].

Nie zawsze procesom sporządzania planów towarzyszy ocena skutków proponowanych rozwiązań planistycznych dla środowiska czy też budżetu gminy (np. koszty rekompensat $\mathrm{z}$ tytułu naruszenia interesów prawnych obywateli) oraz ocena potrzeb, preferencji i aspiracji mieszkańców na objętym planem przestrzennym obszarze, co może powodować na etapie realizacji brak powszechnej akceptacji społecznej dla przyjętych rozwiązań.

Szereg problemów związanych z planowaniem miejscowym oraz realizacją uchwalonych planów wynika bezpośrednio z zapisów obowiązującej ustawy o zagospodarowaniu przestrzennym. Eksperci z tej dziedziny zwracają uwagę na następujące najważniejsze problemy [Topczewska, 1998]:

- pominięcie społeczno-gospodarczych uwarunkowań zagospodarowania przestrzennego przy opracowywaniu studium gminnego;

- brak sprecyzowanych relacji między studium a planami miejscowymi i decyzjami o warunkach zabudowy i zagospodarowania terenów;

- brak możliwości sporządzania studium dla zespołu gmin, choć dostrzegana jest taka potrzeba np. dla obszarów metropolitalnych;

- brak upublicznienia sposobu opracowania studium gminnego (np. w odpowiednim rozporządzeniu wykonawczym);

- brak sprecyzowania obszaru i przedmiotu planu miejscowego;

- niejednoznaczność trybu uzgodnień planu $\mathrm{z}$ właściwymi dla tego celu organami;

- brak dokonywania ocen realizacji polityki przestrzennej gminy, wyrażonej w studium i planach miejscowych.

Autorzy licznych opracowań dotyczących problematyki planowania przestrzennego na poziomie gminy podkreślają również inne mankamenty obowiązującej procedury planowania [System studiów i planów, 2000]. Jednym z nich jest brak podstawowych materiałów niezbędnych do sporządzenia planu miejscowego. Urzędy wielu gmin, nie mając prawnego obowiązku, nie czują potrzeby gromadzenia materiałów informacyjnych, charakteryzujących gospodarkę i stan zagospodarowania gminy. Często barierą bywa brak w ośrodkach geodezyjno-kartograficznych odpowiednich aktualnych map terenu, co powoduje konieczność opracowywania map na koszt urzęéów gmin (wyższe koszty planu miejscowego) lub doprowadza do zaniechania przedsięwzięcia.

W wielu przypadkach opracowywanie i uchwalanie planów oraz posługiwanie się nimi przy wydawaniu decyzji administracyjnych utrudnia niski poziom wiedzy na temat planowania przestrzennego wśród radnych, a także urzędników gmin, zwłaszcza tych mniejszych. 
Nowa ustawa o planowaniu i zagospodarowaniu przestrzennym, której ostateczny tekst przyjęto na posiedzeniu Sejmu w dniu 27 marca 2003 roku, próbuje wyeliminować niektóre $\mathrm{z}$ wymienionych nieprawidłowości systemu planowania i gospodarowania przestrzenią w gminach. Jej zapisy między innymi:

- włączają społeczność lokalną w proces planowania przestrzennego już na etapie opracowywania studium uwarunkowań i kierunków zagospodarowania przestrzennego, które poddawane ma być publicznemu oglądowi i ocenie; - dla obszarów, których zagospodarowanie może wywoływać kontrowersje w lokalnym środowisku oraz stwarzać okazję do zachowań korupcyjnych, takich jak np. obszary przewidziane pod lokalizację wielkopowierzchniowych obiektów handlowych, obligują władze gminy do obowiązkowego opracowania planu miejscowego;

- zwiększają szczegółowość tworzonych planów miejscowych i eliminują tym samym potrzebę wydawania decyzji o warunkach zabudowy i zagospodarowania terenu w obrębie obszarów objętych planem - podstawą uzyskiwania przez inwestorów pozwoleń na budowę będzie plan;

- przewidują konsultacje podejmowanych w planach zagospodarowania przestrzennego rozstrzygnięć z członkami specjalnych organów doradczych składających się z osób o wykształceniu i przygotowaniu fachowym, związanym bezpośrednio z teorią i praktyką planowania przestrzennego;

- uwzględniają konieczność sporządzania prognozy finansowej uchwalania planu;

- przewidując potrzebę stałej aktualizacji studium i planów miejscowych, obligują władze gminy do dokonywania analizy zmian w zagospodarowaniu przestrzennym gminy, oceny postępów w opracowywaniu planów miejscowych oraz opracowywania wieloletnich programów ich sporządzania.

\section{Bibliografia}

Dutkowska A., [2002], Nieprawidlowości przy budowie marketów, „Gazeta Samorządu i Administracji" $\mathrm{nr} 12$.

Jendra M., [2000], Aktywne zarzadzanie gruntami, „Gazeta Samorządu i Administracji” nr 18/19.

Kłosiewicz-Górecka U., Słomińska B., [2002], Badanie wptywu lokalizacji wielkopowierzchniowych obiektów handlowych na otoczenie rynkowe (kontekst ustawy o zagospodarowaniu przestrzennym), IRWiK, Warszawa 2002 (maszynopis powiel.).

Krajewski K., [2000], Lokalny program rozwoju przedsiębiorczości, „Gazeta Samorządu i Administracji" nr 5.

System studiów i planów zagospodarowania przestrzennego po reformie administracyjnej pañstwa. [2000], Redakcja Wysocka E. Instytut Gospodarki Przestrzennej i Komunalnej, Warszawa.

Topczewska T., Frankowski Z., Rezmer Z., Siemiński W., [1998], Próba oceny funkcjonowania ustawy o zagospodarowaniu przestrzennym w planowaniu miejscowym, [w:] Planowanie przestrzenne skutecznym instrumentem rozwoju kraju. Ogólnopolska Konferencja Planowania Przestrzennego ARSENAŁ IX, Wroclaw, 9-10 listopada 1998. Urząd Mieszkalnictwa i Rozwoju Miast.

Ziobrowski Z., Skutecznosć planowania przestrzennego na poziomie podstawowym, [w:] Planowanie przestrzenne skutecznym instrumentem rozwoju kraju. Ogólnopolska Konferencja Plano- 
wania Przestrzennego ARSENAŁ IX, Wrocław, 9-10 listopada 1998. Urząd Mieszkalnictwa i Rozwoju Miast.

\section{SPATIAL PLANNING IN SOCIO-ECONOMIC DEVELOPMENT OF GMINAS}

\section{Summary}

The article is an analysis of spatial planning in socio-economic development of Polish gminas (municipalities), including local market development. In particular, the role of spatial management plan has been characterised as a regulator of trade development and an instrument of stimulating local entrepreneurship.

The article presents results of a survey carried out in 2002 by the Institute of Internal Market and Consumption in 450 Polish gminas representing cities with poviat status, urban gminas and urban-rural gminas, to analyse gminas' approaches in the area of spatial planning and regulation of trade development on local markets, as well as to learn their opinion on enforcement of the Law on Spatial Management in the aspect of location of large-area commercial facilities. 